\title{
A Comparison of Maize Stalk Rot Occurrence in Bt and Non-Bt Hybrids
}

\author{
E. W. Gatch, Department of Plant Pathology, Iowa State University, Ames 50011; R. L. Hellmich, USDA-ARS \\ Corn Insects and Crop Genetics Research Unit and Department of Entomology, Iowa State University; and G. P. \\ Munkvold, Department of Plant Pathology, Iowa State University
}

\begin{abstract}
Gatch, E. W., Hellmich, R. L., and Munkvold, G. P. 2002. A comparison of maize stalk rot occurrence in Bt and non-Bt hybrids. Plant Dis. 86:1149-1155.

Stalk rots, caused by a complex of fungal species, are among the most widespread and destructive diseases of maize. Larvae of the European corn borer (ECB) (Ostrinia nubilalis) promote stalk rot development by creating entry points for fungi, serving as vectors of pathogens, and causing physiological stress that may predispose plants to stalk decay. Field experiments were conducted in 1998, 1999, and 2000 to determine whether the use of transgenic Bt hybrids expressing insecticidal proteins would influence stalk rot symptoms (pith disintegration, pith discoloration, and lodging). Five hybrids representing different Bt types (or "Bt events") (176, BT11, MON810, DBT418, and CBH351) were paired with their near-isogenic, non-Bt counterparts and subjected to treatments of manual and natural infestation with ECB larvae. Manual infestation resulted in significantly more ECB tunneling than natural infestation in 1998 and 1999 and significantly more lodging in 1998. There were significant linear correlations between ECB injury and stalk rot symptoms in non-Bt hybrids in 1998 and 1999, but not in 2000. A standard foliar insecticide treatment for ECB did not significantly affect stalk rot symptoms. In 1998, Bt hybrids had significantly less ECB tunneling, stalk discoloration, pith disintegration, and lodging compared with non-Bt hybrids, but these effects depended upon the Bt event and the infestation treatment. Similar but less pronounced effects of Bt events were observed in 1999. The 2000 results were more variable; the amount of pith disintegration was significantly lower but discoloration was significantly higher in the BT11 hybrid compared with its non-Bt counterpart, and the amount of lodging was significantly higher in the event 176 hybrid compared with its non-Bt counterpart. The ratio of stalk strength to grain weight did not consistently differ between Bt and non-Bt hybrids. These results indicate that, although specific Bt events in some years may cause reductions in stalk rot, the overall effect of Bt transformation on stalk rot occurrence is highly variable.
\end{abstract}

Additional keywords: corn, GMO, Zea mays

Stalk rot is one of the most persistent and destructive diseases of maize throughout the world. The stalk rot complex comprises several fungal pathogens and secondary colonizers (15). The most common stalk rot pathogens in the United States include Gibberella zeae (Schwein.) Petch, Colletotrichum graminicola (Ces.) G. W. Wils., and Fusarium verticillioides (Sacc.) Nirenberg $(16,27)$. Losses in the form of reduced grain-fill and premature death can occur when these pathogens invade maize stalks prior to physiological maturity (15).

Corresponding author: G. P. Munkvold E-mail: munkvold@iastate.edu

This is Journal Paper No. J-19765 of the Iowa Agriculture and Home Economics Experiment Station, Ames, IA, Project No. 3549, supported by Hatch Act and State of Iowa funds. This work was partially supported by grants from the USDA North Central IPM Grant Program, the Leopold Center for Sustainable Agriculture, and Syngenta Seeds, Inc.

Accepted for publication 3 June 2002.

Publication no. D-2002-0815-02R

(C) 2002 The American Phytopathological Society
Destruction of the pith tissue also predisposes the plants to lodging.

Stalk rot fungi overwinter in infected plant residue and invade maize plants through natural entry points such as nodes, through wounds created by insects or mechanical damage, or by direct penetration of root and stalk tissue $(1,9,14,15,26)$. Plants are predisposed to stalk rot by any stress that reduces the photosynthetic capacity of the plant following anthesis, when the developing ear competes with the stalk for carbohydrates $(8,25)$. The traditional and most effective strategies for stalk rot management are to alter cultural practices to minimize the stresses that increase plant susceptibility to fungal invasion and to select locally adapted hybrids with partial resistance to stalk rot (19).

Injury due to feeding by European corn borers (ECBs), Ostrinia nubilalis (Hübner) (order Lepidoptera, family Crambidae), is one stress that can promote the progression of stalk rot $(6,27)$. The ECB is one of the most economically important insect pests of maize, causing an estimated $\$ 1$ billion in losses annually (18). ECB larvae can contribute to the development of stalk rot in several ways. By tunneling through stalk tissue, they create entry points for fungal invasion, serve as vectors of some fungal pathogens, and cause physiological stress that can predispose maize plants to stalk rot development $(3,6,7,12,26)$. This relationship between ECB damage and stalk rot is an important factor in pest management decision making, because the yield loss attributed to ECBs often is due in part to subsequent fungal decay of tissue injured by the larvae $(7,13)$.

Because of the association between ECB injury and fungal stalk rot, control of this insect is recommended as one component of an integrated stalk rot management strategy (19). The most effective way to prevent ECB injury is through the use of transgenic Bt hybrids, available to growers since 1996 (22). Bt hybrids are created by the insertion into the maize genome of a bacterial gene that codes for production of one of several insecticidal proteins (5). These proteins first were isolated from Bacillus thuringiensis, a soilborne bacterium that is pathogenic to specific groups of insects. Genes encoding three lepidopteran-specific $\mathrm{Bt}$ proteins (Cry1Ab, Cry1Ac, and Cry9C) have been used in commercially released maize hybrids $(5,11)$. Accompanying these coding sequences is either a Cauliflower mosaic virus (CaMV) 35S promoter or a combination of a phosphoenolpyruvate carboxylase (PEPC) promoter and a pollen-specific promoter (17).

The combination of Bt protein and promoter sequence, along with the specific insertion event, define a transformation type or event, the term commonly used to distinguish the six separate transformations that have been registered by the Environmental Protection Agency (EPA) for commercial use. These transformation types (or events) are designated as 176 (Ciba Seeds, Greensboro, NC), BT11 (Northrup King, Golden Valley, MN), MON810 (Monsanto Co., St. Louis, MO), DBT418 (DeKalb Plant Genetics, DeKalb, IL), CBH 351 (AgrEvo USA Co., Apple Valley, MN), and TC1507 (Dow AgroSciences, Indianapolis, IN). MON810 and BT11 are in the most widely planted Bt hybrids. Event 176, DBT418, and CBH351 hybrids have not been re-registered; therefore, after their current EPA registration expires, they will not be sold. Transformation types differ in the specific Bt protein expressed and the location of expression in the plant tissue and, therefore, vary in the efficacy of ECB control they provide (5). 
Few scientific investigations have been undertaken to determine precisely how, if at all, the presence of $\mathrm{Bt}$ proteins in maize hybrids will influence pest management strategies other than insect protection. In contrast to the reported direct relationship between insect injury and infection by pathogenic fungi $(3,6,7,12,26)$, an alternative hypothesis suggests that ECB injuries are not important sites for stalk rot infection, and that the increased yields of $\mathrm{Bt}$ hybrids and the added energy cost of producing Cry proteins may weaken stalks and increase their susceptibility to fungal invasion (J. Dodd, personal communication). Existing data on the effects of $\mathrm{Bt}$ transformation on stalk rot are inconclu- sive. Bergstrom et al. (2) found significant reductions in anthracnose stalk rot symptoms in Bt hybrids compared with their near-isogenic, non-Bt counterparts. In preliminary field experiments comparing stalk rot symptoms in Bt and non-Bt hybrids, we obtained similar results but observed variation among locations and events in their effect on stalk rots (20). A study by Reimers et al (23) found no correlation between the incidence of stalk rot and the use of Bt hybrids. The conflicting results of these studies, as well as the unexplored issue of stalk strength in $\mathrm{Bt}$ hybrids, provided a basis for the present study. The objectives of our research were to determine the effects of five Bt transfor-

Table 1. Maize hybrid representatives of five Bt transformation types (events) and their nearisogenic, non-Bt counterparts used in field experiments conducted near Ames, IA in 1998, 1999, and 2000

\begin{tabular}{|c|c|c|c|}
\hline Bt event & 1998 & 1999 & 2000 \\
\hline 176 (KnockOut) $^{\mathrm{v}}$ & NK (Ciba) MAX21 & NK (Ciba) MAX21 & NK (Ciba) MAX454 \\
\hline Non-Bt & NK (Ciba) 4349 & NK (Ciba) 4394 & NK (Ciba) 4494 \\
\hline Bt11 (Yieldgard)w & NK 4640Bt & NK 7070Bt & NK 7070Bt \\
\hline Non-Bt & NK 4640 & NK 7070 & NK 7070 \\
\hline MON810 (Yieldgard) ${ }^{\mathrm{x}}$ & Pioneer 34R06 & Pioneer 34R06 & Pioneer 34R06 \\
\hline Non-Bt & Pioneer 3489 & Pioneer 3489 & Pioneer 3489 \\
\hline DBT418 (BtXtra) ${ }^{\mathrm{y}}$ & DK 566Bt & DK 595Bt & DK 595Bt \\
\hline Non-Bt & DK 566 & DK 595 & DK 595 \\
\hline CBH351 (StarLink $)^{\mathrm{z}}$ & Garst $8600 \mathrm{Bt}$ & Garst 8539 BLT & Garst 8539 BLT \\
\hline Non-Bt & Garst 8600 & Garst 8539 IT & Garst 8539 IT \\
\hline
\end{tabular}

v Ciba Seeds, Greensboro, NC.

${ }^{\text {w}}$ Northrup King Co., Golden Valley, MN.

${ }^{x}$ Monsanto Co., St. Louis, MO.

y DeKalb Plant Genetics, DeKalb, IL.

${ }^{\mathrm{z}}$ Garst Seeds, Inc., Slater, IA.

mation types on the incidence and severity of stalk rot symptoms and lodged stalks and on the relationship between stalk strength and grain weight.

\section{MATERIALS AND METHODS}

Field experiments were conducted in 1998, 1999, and 2000 in the vicinity of Ames, IA. Each year, five Bt hybrids and their near-isogenic non-Bt counterparts (Table 1) were evaluated in field plots arranged in a randomized complete block design with two treatments and eight replications (total of 160 plots). Fields were located at the Iowa State University Johnson farm (Story County) in 1998, Woodruff farm (Boone County) in 1999, and the Agronomy and Agricultural Engineering Research farm (Boone County) in 2000. All fields were in a maize-soybean rotation and were field-cultivated prior to planting between mid- and late May. Standard fertilization and weed management practices were applied in all fields. Plots consisted of four rows $5.33 \mathrm{~m}$ in length planted at a density of 123,000 seeds/ha and thinned to approximately 69,000 plants/ha, with plants spaced 15 to $20 \mathrm{~cm}$ apart. This population is consistent with current commercial practices and the uniform spacing served to standardize competition between neighboring plants. Plots of each hybrid were subjected to two treatments: (i) manual infestation, consisting of two ECB infestations, one at growth stage V8 to V9 (mid-whorl) and one at growth stage R1 (silk stage) (24); and (ii) natural infestation

Table 2. $P$ values for the effects of brand, Bt transformation (Bt), and manual or natural European corn borer (ECB) infestation (Trt) on European corn borer injury (tunneling) to stalks, stalk discoloration, pith disintegration, and lodging in maize field experiments near Ames, IA in 1998, 1999, and 2000 ${ }^{\mathrm{w}}$

\begin{tabular}{|c|c|c|c|c|c|c|}
\hline Year, effect & $\begin{array}{l}\text { ECB tunneling } \\
\qquad(\mathbf{c m})^{\mathrm{x}}\end{array}$ & $\begin{array}{l}\text { Stalk discoloration } \\
(\mathbf{c m})^{\mathrm{x}}\end{array}$ & $\begin{array}{c}\text { Incidence of pith } \\
\text { disintegration }(\% \text { stalks })^{x}\end{array}$ & $\begin{array}{c}\text { Severity of pith } \\
\text { disintegration }(\mathbf{c m})^{\mathrm{x}}\end{array}$ & Lodging $^{y}$ & $\begin{array}{l}\text { Stalk strength: } \\
\text { grain weight }^{\mathrm{z}}\end{array}$ \\
\hline \multicolumn{7}{|l|}{1998} \\
\hline Brand & 0.69 & $<0.01$ & $<0.01$ & $\ldots$ & $<0.01$ & $<0.01$ \\
\hline $\mathrm{Bt}$ & $<0.01$ & 0.02 & $<0.01$ & $\ldots$ & $<0.01$ & 0.35 \\
\hline Trt & 0.03 & 0.38 & 0.52 & $\ldots$ & 0.04 & 0.12 \\
\hline Brand $x$ Bt & 0.02 & 0.68 & 0.98 & $\ldots$ & $<0.01$ & 0.51 \\
\hline Brand $\mathrm{x}$ Trt & 0.74 & 0.23 & 0.19 & $\ldots$ & 0.08 & 0.49 \\
\hline Trt $x$ Bt & 0.02 & 0.05 & 0.05 & $\ldots$ & 0.08 & 0.21 \\
\hline Brand $x$ Bt $x$ Trt & 0.68 & 0.46 & 0.46 & $\ldots$ & 0.21 & 0.73 \\
\hline \multicolumn{7}{|l|}{1999} \\
\hline Brand & 0.05 & $<0.01$ & $<0.01$ & $<0.01$ & $<0.01$ & $<0.01$ \\
\hline $\mathrm{Bt}$ & $<0.01$ & 0.90 & 0.87 & 0.75 & 0.26 & 0.95 \\
\hline Trt & 0.01 & 0.99 & 0.75 & 0.73 & 0.99 & 0.86 \\
\hline Brand $x$ Bt & 0.02 & $<0.01$ & 0.03 & $<0.01$ & 0.84 & 0.19 \\
\hline Brand $x$ Trt & $<0.01$ & 0.50 & 0.88 & 0.55 & 0.92 & 0.14 \\
\hline Trt $x$ Bt & 0.24 & 0.33 & 0.43 & 0.84 & 0.52 & 0.10 \\
\hline Brand $x$ Bt $x$ Trt & $<0.01$ & 0.79 & 0.60 & 0.33 & 0.99 & 0.19 \\
\hline \multicolumn{7}{|l|}{2000} \\
\hline Brand & 0.01 & $<0.01$ & 0.10 & $<0.01$ & $<0.01$ & $<0.01$ \\
\hline $\mathrm{Bt}$ & $<0.01$ & 0.34 & 0.69 & $<0.01$ & 0.22 & 0.99 \\
\hline Trt & 0.06 & 0.43 & 0.87 & 0.48 & 0.10 & 0.32 \\
\hline Brand $x$ Bt & 0.36 & $<0.01$ & 0.33 & 0.05 & $<0.01$ & 0.73 \\
\hline Brand $\mathrm{x}$ Trt & 0.06 & 0.84 & 0.36 & 0.26 & 0.45 & 0.73 \\
\hline Trt $x$ Bt & 0.03 & 0.86 & 0.70 & 0.01 & 0.06 & 0.59 \\
\hline Brand $\mathrm{x}$ Bt $\mathrm{x}$ Trt & 0.10 & 0.59 & 0.34 & 0.79 & 0.08 & 0.99 \\
\hline
\end{tabular}

${ }^{\mathrm{w}}$ Brand is the company of origin of each maize hybrid. Each brand represents a different Bt type; manual infestation consisted of applying 50 neonatal larvae to the whorl (at growth stage V8-V9) or ear-leaf axil (at stage R1) of each plant; ... = not measured.

${ }^{x}$ Based on eight replicates of four stalks each.

${ }^{y}$ Measured as proportion of lodged stalks, based on eight replicates of six stalks each.

${ }^{\mathrm{z}}$ Measured as average ratio of stalk strength to grain weight, based on eight replicates of six stalks each. 
(no manual infestations). Larvae for the manual infestations were reared at the United States Department of AgricultureAgricultural Research Service Corn Insects Laboratory in Ames and applied to plants using an applicator that delivered about 50 neonatal larvae mixed with ground maize cobs to the whorl at V8 to V9 and to the axil of the ear shank at R1 (21). Each of the infestations was performed twice within a 1-week period. An additional treatment carried out in 1999 and 2000 consisted of applications of a permethrin insecticide (Pounce 3.2 EC: FMC Co., $167.4 \mathrm{~g}$ a.i./ha) on the day after each infestation treatment (four applications total) to the non-Bt isoline of transformation type MON810. The applications were made to the two middle rows of the four-row plots. This treatment was randomized along with the other treatments so that there was a total of 168 plots in 1999 and 2000. No inoculations of stalk rot pathogens were made, because these fungi are present naturally in crop residue and soil.

Stalks were sampled at physiological maturity (R6), as indicated by formation of a black layer on the kernel. Sampling consisted of systematic selection of four stalks (every fifth or sixth stalk) from an inner row of each four-row plot. Stalks were excised at the base with a pruning shears and trimmed back four nodes above the ear node, with the upper internodes subsequently discarded. The remainder of the stalk was split longitudinally. The split stalks were evaluated for the length $(\mathrm{cm})$ of stalk discoloration, ECB tunneling, and pith disintegration. Pith disintegration was defined as stalk tissue in which the pith was thoroughly decayed, leaving only the vascular bundles intact. We interpreted stalk discoloration as an early stage in stalk rot development and therefore distinguished it from pith disintegration, a symptom that better typifies fully developed stalk rot. In 1998, the incidence (presence or absence) of pith disintegration was determined; in the following two years, this procedure was modified to include measurement of the length of disintegrated pith in the stalks to estimate stalk rot severity as well as incidence. Six additional stalks per plot were systematically sampled for determination of stalk strength in relation to grain weight. From each stalk, the ear and the internode approximately $50 \mathrm{~cm}$ from ground level were collected. The ears were placed in cloth bags, refrigerated, and later shelled. The shelled kernels were weighed and moisture content determined using a Dole 400 Moisture Tester (Eaton Corporation, Carol Stream, IL). Grain weights for individual ears were calculated based on kernel weights corrected with moisture readings. The strength of the internodes was evaluated with the Instron Materials Tester (Instron Corp., Canton, MA), an instrument that subjected the internodes to a tangential compressive force and measured the resistance in kilograms to the compression (10). This internode strength measurement was used to calculate the ratio of stalk strength to grain weight for each plant.

Approximately 30 days following physiological maturity of the plants, lodging was rated as the percentage of lodged stalks in the remaining unsampled inner row of each plot. Only stalks broken below the ear node were counted as lodged.

The SAS statistical package (Statistical Analysis System; SAS Institute, Inc., Cary, NC) was used to carry out all analyses. Analyses of variance were conducted on the means of all sampled plants in each plot for the following variables: length of stalk discoloration, incidence of pith disintegration, length of pith disintegration (except in 1998), length of ECB tunneling, number of ECB larvae found in stalks, and percentage of stalks that were lodged. Four-way analysis of variance (ANOVA) was carried out to determine the main effects of hybrid brand (company of origin of each hybrid), presence of $\mathrm{Bt}$ proteins $(\mathrm{Bt})$, manual or natural infestation (treatment), and replicate block, as well as interactions among these variables. Each hybrid brand contained a different Bt type; therefore, the brand by $\mathrm{Bt}$ interaction was interpreted to represent differential effects among $\mathrm{Bt}$ types. Mean separation was performed using orthogonal contrast analysis. A separate ANOVA was conducted to compare the effects of the foliar insecticide to those of MON810 Bt transformation. Linear correlations were calculated to determine the relationship between ECB injury and stalk rot symptoms.

\section{RESULTS}

There were significant differences $(P \leq$ 0.05 ) in stalk rot (pith disintegration) incidence and severity, lodging, and ECB injury between $\mathrm{Bt}$ hybrids and their non-Bt counterparts, but these effects varied with the year, Bt transformation type, and treatment (level of ECB infestation; Table 2). With few exceptions, the amount of ECB tunneling was significantly less in Bt hybrids compared with their near-isogenic, non-Bt counterparts (Fig. 1). Linear correlations between ECB injury and two symp-

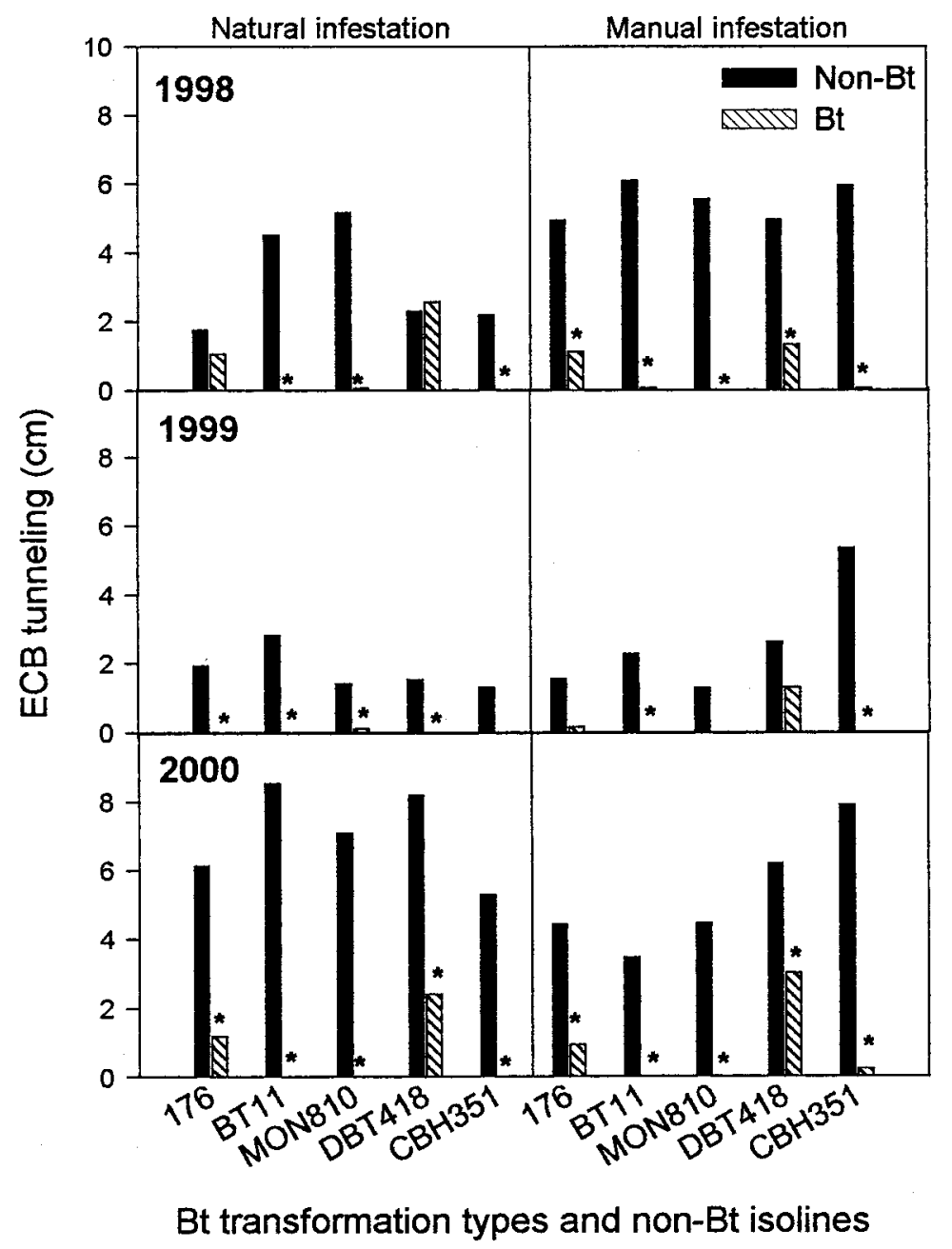

Fig. 1. Extent of European corn borer (ECB) tunneling in Bt maize hybrids compared with their near-isogenic, non-Bt counterparts in field experiments in central Iowa in 1998, 1999, and 2000. Values are based on eight replicates of four stalks each. Asterisks indicate significant differences $(P \leq$ 0.05 ) between $\mathrm{Bt}$ and non-Bt counterparts, according to planned orthogonal contrasts. 
toms of stalk rot, stalk discoloration and pith disintegration, were significantly positive in non-Bt corn, with the exception of the 2000 experiment (Table 3). There were no significant linear correlations between ECB injury and lodging in any of the 3 years (Table 3).

In 1998, manual infestation with ECB larvae resulted in significantly more ECB tunneling (mean $5.5 \mathrm{~cm}$ ) than the natural infestation (mean $3.2 \mathrm{~cm}$ ) in non-Bt hybrids. This effect was limited to certain hybrid brands in 1999; in 2000, tunneling was not increased by manual infestation
(Fig. 1, Table 2). In 1998 and 2000, there were significant interactions between the effects of infestation treatment and $\mathrm{Bt}$ on some stalk rot symptoms (Table 2). In the manual infestation treatment in 1998, there was significantly less stalk discoloration (35.5 versus $62.1 \mathrm{~cm}$ ) and a lower incidence of pith disintegration (19 versus $54 \%$ ) in Bt hybrids compared with non-Bt hybrids. In the natural infestation treatment in 2000, there was significantly less pith disintegration in $\mathrm{Bt}$ hybrids (mean 36.8 $\mathrm{cm}$ ) compared with non-Bt hybrids (mean $51.5 \mathrm{~cm}$ ) (Table 2).

Table 3. Linear correlation coefficients between European corn borer (ECB) injury ( $\mathrm{cm}$ tunneling) and maize stalk rot symptoms in Bt and non-Bt hybrids in field experiments conducted near Ames, IA in 1998, 1999, and 2000y

\begin{tabular}{|c|c|c|c|c|c|c|}
\hline \multirow[b]{2}{*}{ Year } & \multicolumn{2}{|c|}{ Pith disintegration $(\mathrm{cm})$} & \multicolumn{2}{|c|}{ Stalk discoloration $(\mathbf{c m})$} & \multicolumn{2}{|c|}{ Lodging $^{z}$} \\
\hline & Non-Bt & Bt & Non-Bt & Bt & Non-Bt & Bt \\
\hline 1998 & $0.36^{*}$ & 0.05 & $0.22 *$ & 0.01 & 0.13 & 0.10 \\
\hline 1999 & $0.22 *$ & 0.17 & $0.23 *$ & 0.11 & -0.05 & 0.05 \\
\hline 2000 & 0.12 & 0.11 & 0.15 & -0.11 & -0.07 & -0.06 \\
\hline
\end{tabular}

y Asterisks indicate correlation coefficients significant at $P \leq 0.05$.

${ }^{\mathrm{z}}$ Measured as proportion of lodged stalks.

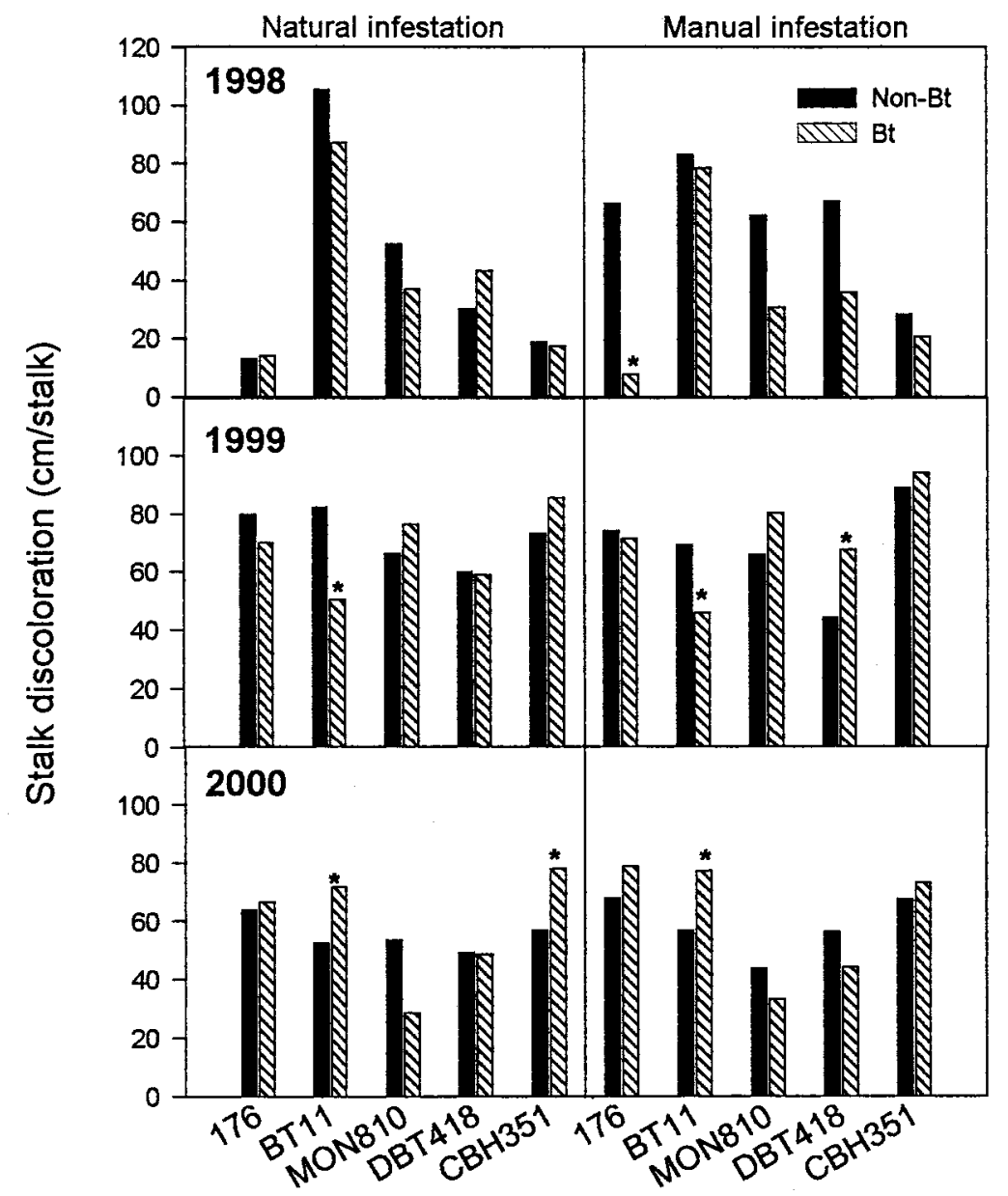

\section{Bt transformation types and non-Bt isolines}

Fig. 2. Extent of stalk discoloration in Bt maize hybrids compared with their near-isogenic, non-Bt counterparts in field experiments in central Iowa in 1998, 1999, and 2000. Values are based on eight replicates of four stalks each. Asterisks indicate significant differences $(P \leq 0.05)$ between Bt and non-Bt counterparts, according to planned orthogonal contrasts.
In each year of the project, there were significant effects of the presence of $\mathrm{Bt}$ proteins or significant interactions between the effects of Bt proteins and hybrid brand on one or more of the stalk rot variables measured (stalk discoloration, pith disintegration, and lodging (Figs. 2-5, Table 2). In 1999, the BT11 hybrid had significantly less stalk discoloration than its non-Bt counterpart, but this effect was reversed in 2000 with significantly less discoloration observed in the non-Bt counterpart (Fig. 2). Incidence of pith disintegration was significantly lower in the BT11 hybrid compared with its non-Bt counterpart in 1998 and 1999 in the naturally infested plots (Fig. 3). In 1999 and 2000, reductions in severity of pith disintegration were observed in the BT11 hybrid compared with its non-Bt counterpart (Fig. 4). In 1999, this reduction occurred only in naturally infested plots. In 1998, the BT11 hybrid also had significantly less lodging than its non-Bt counterpart (Fig. 5). Transformation type 176 had a significantly lower incidence of pith disintegration and less lodging in 1998 (manual infestation) and lodging alone in 2000 (Figs. 3 and 5). In 2000, significantly more stalk discoloration (manual infestation) and lodging were observed in transformation type CBH351 than in its non-Bt counterpart (Figs. 2 and 5). In 1998, the same transformation type had a significantly lower incidence of pith disintegration (manual infestation) than its non-Bt counterpart (Fig. 3).

There was no consistent effect of Bt proteins on the ratio of stalk strength to grain weight. This ratio was significantly affected only by hybrid brand (Table 2). Bt transformations did not significantly affect grain weight or stalk strength, except in 1998, when Bt hybrids had significantly stronger stalks and higher grain weights than those of non-Bt hybrids (data not shown).

The effects of the foliar insecticide on stalk rot variables and ECB injury depended on the year. In both 1999 and 2000, the amount of ECB tunneling was significantly less in the Bt hybrid compared with both the sprayed non-Bt and the unsprayed non-Bt counterpart $(P<0.01$; Table 4$)$. In 2000, the Bt hybrid had significantly less stalk discoloration and pith disintegration than the unsprayed non-Bt hybrid, whereas the spray treatment did not significantly differ from the unsprayed (Table 4).

\section{DISCUSSION}

Our research indicates that positive or negative effects of $\mathrm{Bt}$ transformation on stalk health depend to some extent on the specific Bt transformation type used, with BT11 providing some consistent reductions in stalk rot. The effects of the other transformation types were more variable and, for this reason, the interaction between hybrid brand and Bt transformation was of greater interest than overall compar- 


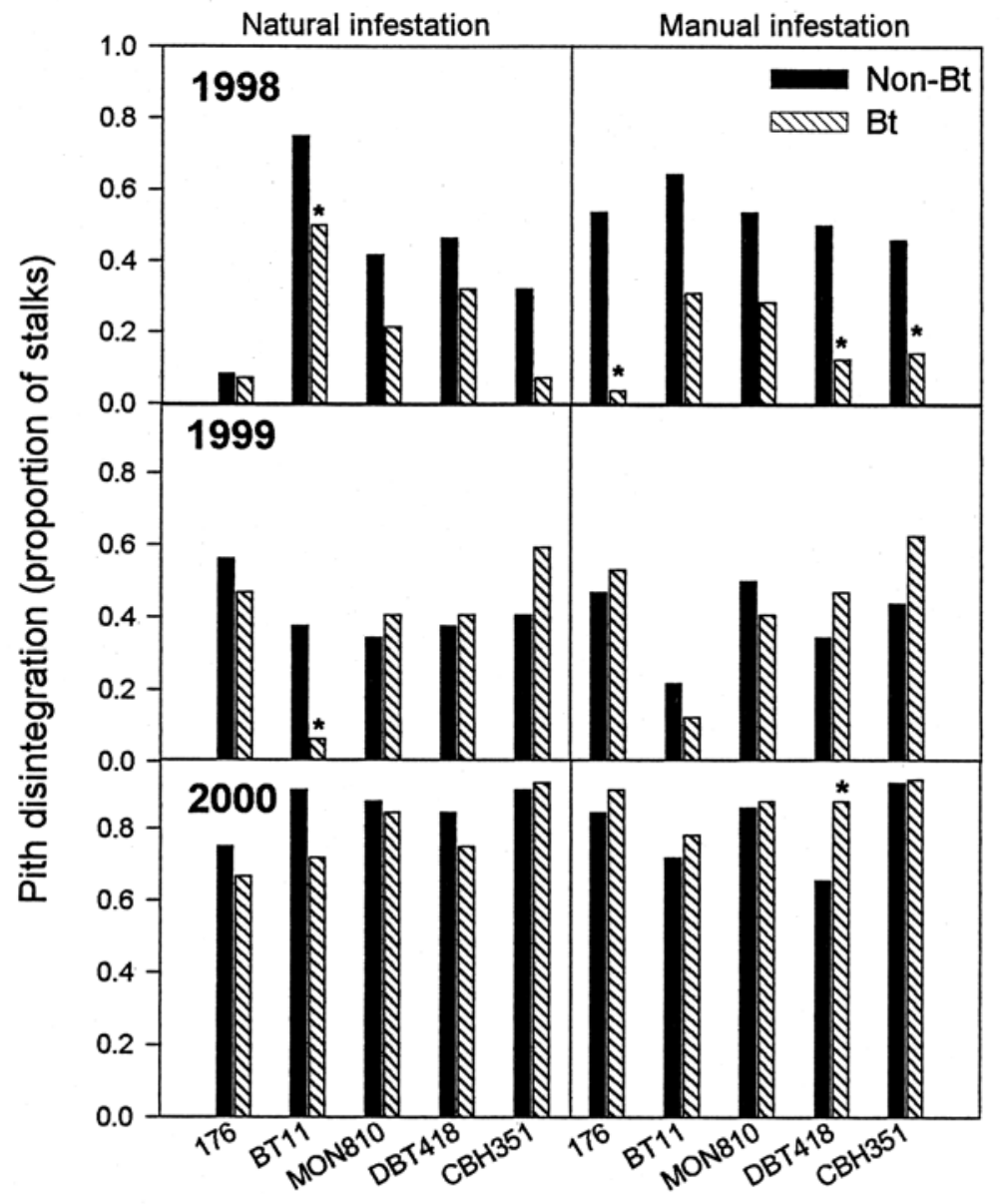

Bt transformation types and non-Bt isolines

Fig. 3. Incidence of stalk pith disintegration in Bt maize hybrids compared with their near-isogenic, non-Bt counterparts in field experiments in central Iowa in 1998, 1999, and 2000. Values are based on eight replicates of four stalks each. Asterisks indicate significant differences $(P \leq 0.05)$ between $\mathrm{Bt}$ and non-Bt counterparts, according to planned orthogonal contrasts.

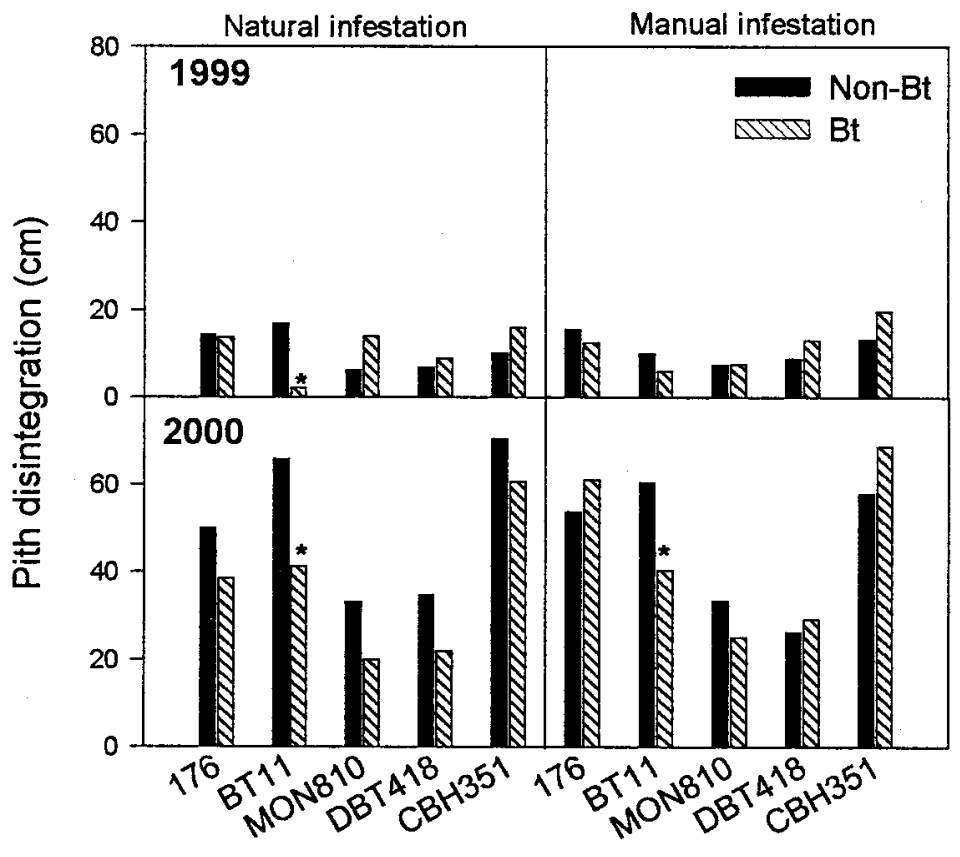

\section{Bt transformation types and non-Bt isolines}

Fig. 4. Extent of stalk pith disintegration in Bt maize hybrids compared with their near-isogenic, non-Bt counterparts in field experiments in central Iowa in 1999 and 2000. Values are based on eight replicates of four stalks each. Asterisks indicate significant differences $(P \leq 0.05)$ between $\mathrm{Bt}$ and non-Bt counterparts, according to planned orthogonal contrasts. isons between $\mathrm{Bt}$ and non-Bt hybrids. In 1998, significant reductions in stalk rot symptoms and lodging were observed in some Bt hybrids compared with their nonBt counterparts, but these results were not confirmed in the following two years. The 1999 experiment produced fewer significant differences but a similar pattern of reduced stalk rot symptoms in some $\mathrm{Bt}$ hybrids. In 2000, however, some Bt hybrids had significantly more stalk discoloration and lodging compared with their non-Bt counterparts. High levels of stalk rot occurred throughout the state in 2000 (G. P. Munkvold, unpublished data) and were more closely related to drought stress (8) than to ECB injury. A possible interpretation of these results is that the contribution of Bt hybrids to stalk rot management is not evident when ECB injury is not a primary factor in stalk rot development.

Transformation type $\mathrm{CBH} 351$ provides additional insight into the interaction between Bt proteins and stalk rot in the 2000 experiment. With little ECB injury in the natural infestation, the $\mathrm{Bt}$ hybrid representing this transformation type had significantly more lodging than its non-Bt counterpart. When ECB injury was more severe (the manual infestation), the Bt hybrid had significantly less lodging than its non-Bt counterpart. Together, these results demonstrate that, when the ECB population is low, there is no advantage conferred by the presence of Bt proteins.

There was no consistent effect of $\mathrm{Bt}$ transformation on the ratio of stalk strength to grain weight; the hypothesis that the increased yields often reported with $\mathrm{Bt}$ hybrids occur at the expense of stalk strength therefore is not supported by our data. It must be noted, however, that although standard estimates of expected yield losses associated with ECB larvae exist (4), we observed little or no reduction in grain weight in non-Bt hybrids compared with Bt hybrids.

Other factors may have obscured differences between $\mathrm{Bt}$ and non-Bt hybrids in this project. The correlations between ECB tunneling and stalk rot symptoms were significantly positive in two out of three years, but were overall fairly low $(r=0.22$ to 0.36) compared with the findings of previous research $(6,12)$. It was apparent from comparisons of manual and natural infestation that the survival of manually infested ECB larvae in the field was low, and we were thus unsuccessful in simulating severe ECB pressure in the manual infestation plots. Natural ECB populations were lower than normal in each year of the study, which further limited the discerning power of our experiments. In years of severe ECB infestation, 12 to $15 \mathrm{~cm}$ of larval tunneling per stalk would not be unusual; in our experiments, the overall mean stalk tunneling was approximately $2 \mathrm{~cm}$ (Fig. 1). 
Perhaps the most important factor influencing the results of this research is the complexity of the interaction between stalk rot and the environment. In the absence of insect damage, there are still many plant stresses that contribute to stalk rot development, and they vary unpredictably among experiments. During the 3 years of our study, there was a pattern of above-average spring rainfall, below-average late-summer rainfall, and above-average late-summer temperatures. The magnitude of these departures from normal differed among seasons, with 2000 having the most extreme

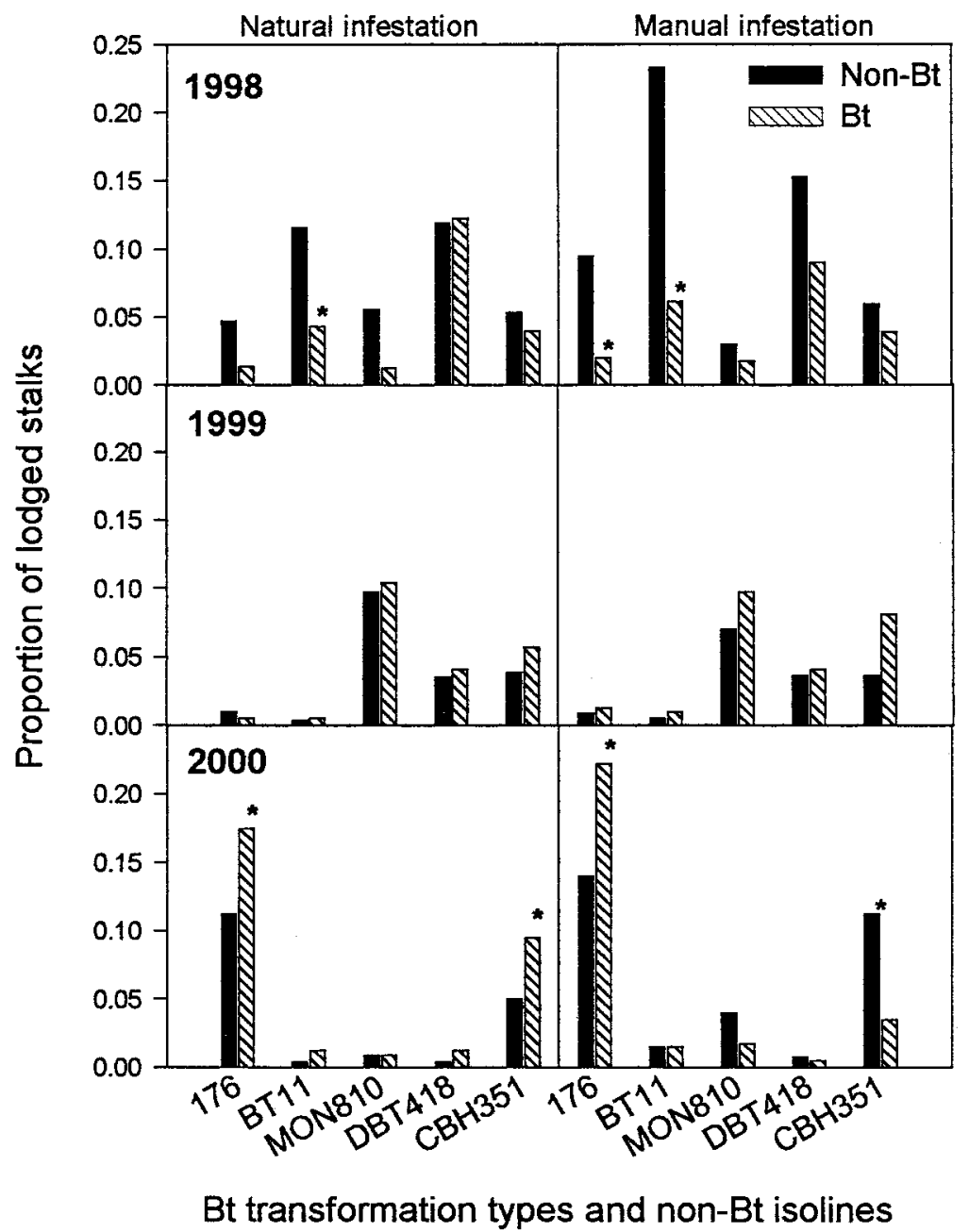

Fig. 5. Amount of lodging in Bt maize hybrids compared with their near-isogenic, non-Bt counterparts in field experiments in central Iowa in 1998, 1999, and 2000. Values are based on eight replicates of six stalks each. Asterisks indicate significant differences $(P \leq 0.05)$ between $\mathrm{Bt}$ and nonBt counterparts, according to planned orthogonal contrasts.

Table 4. Effects of a foliar insecticide and Bt transformation (Bt) on maize stalk rot symptoms and European corn borer (ECB) injury to stalks (tunneling) in field experiments conducted in 1999 and 2000 near Ames, IA ${ }^{\mathrm{w}}$

\begin{tabular}{lccc}
\hline Year, treatment & Stalk discoloration $(\mathbf{c m})$ & Pith disintegration $(\mathbf{c m})$ & ECB tunneling $(\mathbf{c m})$ \\
\hline 1999 & & & \\
$\mathrm{Bt}^{\mathrm{x}}$ & $78.4 \mathrm{a}$ & $10.6 \mathrm{a}$ & $0.05 \mathrm{~b}$ \\
Insecticide $^{\mathrm{y}}$ & $69.4 \mathrm{a}$ & $13.2 \mathrm{a}$ & $0.92 \mathrm{a}$ \\
Control $^{\mathrm{z}}$ & $64.9 \mathrm{a}$ & $6.7 \mathrm{a}$ & $1.4 \mathrm{a}$ \\
2000 & & & \\
$\mathrm{Bt}^{\mathrm{x}}$ & $30.8 \mathrm{~b}$ & $22.3 \mathrm{~b}$ & $0.0 \mathrm{c}$ \\
Insecticide $_{\text {Control }^{\mathrm{z}}}$ & $38.6 \mathrm{ab}$ & $29.0 \mathrm{ab}$ & $2.7 \mathrm{~b}$ \\
\hline
\end{tabular}

${ }^{w}$ Effects for manual and natural infestation combined. Values followed by the same letter within each year and symptom type are not significantly different $(P \leq 0.05)$, according to orthogonal contrasts.

x Pioneer hybrid 34R06 (near-isogenic with 3489).

${ }^{y}$ Permethrin insecticide (Pounce 3.2 EC:FMC Co., $167 \mathrm{~g}$ a.i./ha) applied after each manual infestation to non-Bt hybrid (Pioneer hybrid 3489) at growth stages V8-V9 and R1.

z Pioneer hybrid 3489.

conditions (and most favorable for stalk rot). The variable weather among seasons undoubtedly influenced the results. In future field experiments, it would be advantageous to devise an infestation procedure that would ensure high survival of infested larvae, as well as high levels of insect damage, under a broad range of weather conditions, in order to compare the impact of Bt proteins on stalk rot under conditions of a severe ECB infestation.

Despite these complicating factors, our research indicates that specific Bt transformation types may be more likely than others to contribute to stalk rot management. Reductions in pith disintegration were observed in BT11 compared with its nonBt counterpart in 1998 (natural infestation), 1999 (natural infestation), and 2000. BT11 also had significantly reduced lodging in 1998. In similar work with Bt hybrids and Fusarium ear rot infections, some transformation types more effectively reduced ear rot incidence and severity than others $(20,21)$. In addition to confirming this inherent variability among transformation types, our observations demonstrate a need for further investigation of stalk rot in Bt hybrids under conditions of a severe ECB infestation.

\section{ACKNOWLEDGMENTS}

We thank J. Shriver for technical assistance in the field and laboratory; C. Martinson for advice, technical assistance, and for reviewing the manuscript; and J. Dyer, USDA-ARS Corn Insects and Crop Genetics Research Unit, for generously supplying European corn borer larvae.

\section{LITERATURE CITED}

1. Bailey, J. A., O'Connell, R. J., Pring, R. J., and Nash, C. 1992. Infection strategies of Colletotrichum species. Pages 88-120 in: Colletotrichum: Biology, Pathology, and Control. $\mathrm{CAB}$ International, Wallingford, Oxon, UK.

2. Bergstrom, G. C., Davis, P. M., and Waldron, J. K. 1997. Management of anthracnose stalk rot/European corn borer pest complex with transgenic Bt corn hybrids for silage production. Biol. Cult. Tests 12:14.

3. Bergstrom, G. C., and Nicholson, R. L. 1999. The biology of corn anthracnose; knowledge to exploit for improved management. Plant Dis. 83:596-607.

4. Bode, W. M., and Calvin, D. D. 1990. Yield loss relationships and economic injury levels for European corn borer (Lepidoptera: Pyralidae) populations infesting Pennsylvania corn. (Abstr.) J. Econ. Entomol. 83:1595-1603.

5. Carozzi, N. B., and Koziel, M. G. 1997. Transgenic maize expressing a Bacillus thuringiensis insecticidal protein for control of the European corn borer. Pages 63-74 in: Advances in Insect Control: The Role of Transgenic Plants. N. B. Carozzi and M. G. Koziel, eds. Taylor and Francis, Philadelphia.

6. Chiang, H. C., and Wilcoxson, R. D. 1961. Interactions between the European corn borer and stalk rot in corn. J. Econ. Entomol. 54:850-852.

7. Christensen, J. J., and Schneider, C. L. 1950. European corn borer (Pyrausta nubilalis Hbn.) in relation to shank, stalk, and ear rots of corn. Phytopathology 40:284-291.

8. Dodd, J. L. 1980. The role of plant stresses in 
development of corn stalk rots. Plant Dis. 64:533-537.

9. Foley, D. C. 1962. Systemic infection of corn by Fusarium moniliforme. Phytopathology 52:870-873.

10. Foley, D. C. 1969. Stalk deterioration of plants susceptible to corn stalk rot. Phytopathology 59:620-627.

11. Hofte, H., and Whitley, H. R. 1989. Insecticidal crystal proteins of Bacillus thuringiensis. Microbiol. Rev. 53:242-254.

12. Jarvis, J. L., Clark, R. L., Guthrie, W. D., Berry, E. C., and Russell, W. A. 1984. The relationship between second-generation European corn borers and stalk rot fungi in maize hybrids. Maydica 29:247-263.

13. Keller, N. P., Bergstrom, G. C., and Carruthers, R. I. 1986. Potential yield reductions in maize associated with an anthracnose/European corn borer complex in New York. Phytopathology 76:586-589.

14. Kingsland, G. C., and Wernham, C. C. 1962. Etiology of stalk rots of corn in Pennsylvania. Phytopathology 52:519-523.

15. Koehler, B. 1960. Cornstalk rots in Illinois. Univ. Ill. Exp. Stn. Bull. 658.

16. Kommedahl, T., and Windels, C. E. 1981. Root-, stalk-, and ear-infecting Fusarium species on corn in the USA. Pages 94-104 in:
Fusarium: Diseases, Biology, and Taxonomy. Pennsylvania State University, University Park.

17. Koziel, M. G., Beland, G. L., Bowman, C., Carozzi, N. B., Crenshaw, R., Crossland, L., Dawson, J., Desai, N., Hill, M., Kadwell, S., Launis, K., Lewis, K., Maddox, D., McPherson, K., Meghji, M. R., Merlin, E., Rhodes, R., Warren, G. W., Martha, M., and Evola, S. V. 1993. Field performance of elite transgenic maize plants expressing an insecticidal protein derived from Bacillus thuringiensis. Bio/Technology 11:194-200.

18. Mason, C. E., Rice, M. E., Calvin, D. D., Van Duyn, J. W., Showers, W. B., Hutchison, W. D., Witkowski, J. F., Higgins, R. A., Onstad, D. W., and Dively, G. P. 1996. European Corn Borer: Ecology and Management. North Cent. Reg. Ext. Publ. No. 327. Iowa State University, Ames.

19. Munkvold, G. P. 1996. Corn stalk rot in Iowa. Iowa State Univ. Ext. Publ. IPM 50.

20. Munkvold, G. P. 1998. Disease control with Bt corn? Integr. Crop Manage. 480:1-3.

21. Munkvold, G. P., Hellmich, R. L., and Showers, W. B. 1997. Reduced Fusarium ear rot and symptomless infection in kernels of maize genetically engineered for European corn borer resistance. Phytopathology
87:1071-1077.

22. Ostlie, K. R., Hutchison, W. D., and Hellmich, R. L. 1997. Bt corn and European Corn Borer. North Cent. Reg. Publ. No. 602. University of Minnesota, St. Paul.

23. Reimers, C. I., Clark, T. L., Kamble, S. T., and Foster, J. E. 1998. Relationship of European corn borer and stalk rots in $\mathrm{Bt}$ and nearisoline non-Bt maize hybrids in southeastern Nebraska Entomol. Soc. Am. North Cent. Branch Meet. (Abstr.) Lanham, MD.

24. Ritchie, S. W., Hanway, J. J., and Benson, G. O. 1992. How a corn plant develops. Iowa State Univ. Ext. Publ. Spec. Rep. No. 48.

25. Smith, D. R. and White, D. G. 1988. Diseases of corn. Pages 687-766 in: Corn and Corn Improvement. American Society of Agronomy, Inc.; Crop Science Society of America, Inc.; and Soil Science Society of America, Inc. Madison, WI.

26. Sobek, E. A., and Munkvold, G. P. 1999 European corn borer (Lepidoptera: Pyralidae) as vectors of Fusarium moniliforme, causing kernel rot and symptomless infection of maize kernels. J. Econ. Entomol. 92:503-509.

27. White, D. G. 1999. Fungal stalk rots. Pages 38-44 in: Compendium of Corn Diseases. 3rd ed. American Phytopathological Society Press, St. Paul, MN. 